\title{
TINJAUAN YURIDIS AKAD JUAL BELI TANAH DENGAN SUBJEK HUKUM ANAK DIBAWAH UMUR
}

\author{
M. Fuad Fatoni, Mahasiswa Fakultas Hukum, Universitas Islam Balitar, Blitar, \\ Email: mfuadfatoni@gmail.com \\ Weppy Susetyo, Dosen Fakultas Hukum, Universitas Islam Balitar, Blitar, \\ E-mail: weppy_s@yahoo.co.id
}

\begin{abstract}
ABSTRAKSI
Perkembangan hukum perdata mengenai pengalihan hak milik atas tanah dan bangunan melalui jual beli di Indonesia mengalami banyak perkembangan. Pada saat ini dapat ditemui praktik jual beli tanah dan bangunan yang berasal dari pemberian hibah/warisan oleh anak yang masih di bawah umur. Bagi seorang anak yang masih di bawah umur yang mempunyai kehendak untuk melakukan perbuatan hukum pengalihan hak objek hibah tersebut memiliki kedudukan yang berbeda dengan subjek hukum yang cakap melakukan perbuatan hukum. Penelitian ini bertujuan untuk memperoleh kepastian mengenai kedudukan anak beserta akibat hukum jual beli atas tanah dan bangunan yang berasal dari hibah/warisan yang dilakukan oleh anak di bawah umur. Metode pendekatan yang digunakan dalam penelitian ini adalah yuridis normatif yang menitikberatkan penelitian terhadap data sekunder sebagai sumber data utama yang didukung oleh data primer. Hasil penelitian menunjukan bahwa kedudukan anak dibawah umur tidak sah melakukan jual beli tanah dan bangunan. Akibat hukumnya adalah jual beli tersebut dapat dibatalkan karena syarat kecakapan bertindak tidak terpenuhi. Solusinya, harus ditunjuk wali untuk mewakili dalam melakukan perbuatan hukum mengalihkan hak milik atas tanah yang menjadi haknya tersebut, melalui Penetapan Wali dari Pengadilan Negeri dalam pembuatan Akta Jual Beli di hadapan Notaris/PPAT dan mendaftarkan peralihan hak atas tanah dalam rangka mendapat perlindungan hukum bagi pihak penerima hasil perolehan jual beli tanah dan bangunan selaku pemegang hak atas tanah yang baru serta demi ketertiban tata usaha pendaftaran tanah sesuai dengan ketentuan dalam Peraturan Pemerintah No. 24 Tahun 1997 tentang Pendaftaran Tanah.
\end{abstract}

Kata kunci : Hukum, Anak, Dibawah umur, Jual beli, Tanah

\section{PENDAHULUAN}

Anak merupakan karunia yang diberikan Tuhan Yang Maha Esa kepada kedua orang tuanya. Setiap anak tidak hanya tumbuh dan berkembang dalam sebuah keluarga, namun juga berkembang ditengah masyarakat. Kelahiran seorang anak menimbulkan hak dan kewajiban yang dimilikinya sebagai subjek hukum bahkan sebelum anak tersebut dilahirkan. Hal ini sebagaimana diatur dalam Pasal 2 Kitab Undang-undang Hukum Perdata yang selanjutnya disebut KUH Perdata, menyebutkan bahwa anak yang ada dalam kandungan seorang perempuan dianggap sebagai telah dilahirkan, bilamana juga kepentingan anak menghendakinya. Perhatian terhadap anak sudah lama ada sejalan dengan peradaban manusia itu sendiri.

Lahirnya Konvensi Perserikatan Bangsa-Bangsa (PBB) tentang Hak-hak Anak pada tanggal 20 November 1989 menandai adanya perhatian terhadap anak secara internasional. Indonesia telah meratifikasi konvensi tersebut melalui Keputusan Presiden Nomor 36 Tahun 1990. Konvensi tersebut memuat kewajiban Negara-negara yang meratifikasinya untuk menjamin terlaksananya hak-hak anak. Berbagai macam hak yang diatur dalam peraturan perundang-undangan tetap membatasi hak seorang anak untuk melakukan perbuatan hukum tertentu. Salah satunya dalam melakukan peralihan hak atas tanah melalui jual beli. Peralihan hak adalah suatu perbuatan hukum yang bertujuan memindahkan hak, antara lain jual beli, hibah, tukar menukar, pemisahan dan pembagian harta bersama, dan pemasukan dalam perusahaan atau inbreng. 
Tanah memiliki kedudukan dan fungsi yang sangat penting dalam kehidupan, salah satunya sebagai tempat tinggal. Kepemilikan hak atas tanah oleh seorang anak berasal dari berbagai sumber, baik yang berasal dari pemberian dengan wasiat, pemberian menurut adat warisan, hibah dari orangtua maupun orang lain kepadanya. Peralihan hak atas tanah melalui jual beli dapat diawali dengan pembuatan akta perikatan jual beli yang dibuat dihadapan Notaris. Istilah perjanjian pengikatan jual beli tanah dengan akta perikatan jual beli memiliki makna yang sama yakni dibuat dihadapan Notaris dan bersifat sementara atau sebagai perjanjian pendahuluan karena untuk kepentingan pendaftaran peralihan hak atas tanah harus dituangkan dalam akta jual beli yang dibuat dihadapan PPAT.

Perikatan yang berasal dari perjanjian jual beli ini harus memenuhi syarat sah jual beli yang tunduk pada Pasal 1320 KUH Perdata, sedangkan untuk proses pembuatan akta jual beli dibuat dihadapan PPAT serta penyerahan yuridis mengenai pendaftaran peralihan hak atas tanahnya tunduk pada Hukum Agraria, yaitu meliputi Undang-undang Nomor 5 Tahun 1960 tentang Peraturan Dasar Pokok-Pokok Agraria yang selanjutnya disebut UUPA, Peraturan Pemerintah Nomor 24 Tahun 1997 tentang Pendaftaran Tanah, dan peraturan pertanahan lainnya. Peralihan hak atas tanah tersebut tidak dapat dilakukan sendiri oleh seorang anak karena tidak adanya kecakapan yang dimiliki oleh seorang anak sebagai subjek hukum dalam melakukan perbuatan hukum tersebut. Salah satu syarat yang harus dipenuhi dalam pembuatan akta perikatan jual beli yaitu mengenai kecakapan bertindak. Pasal 39 Undang-undang Nomor 02 Tahun 2014 tentang Perubahan atas Undang-undang Nomor 30 Tahun 2004 tentang Jabatan Notaris mengatur bahwa yang dapat memenuhi syarat sebagai penghadap adalah seseorang dengan minimal berusia 18 tahun dan cakap melakukan perbuatan hukum. Seorang anak yang masih di bawah umur yang mempunyai kehendak untuk melakukan perbuatan hukum pengalihan hak objek (tanah), memiliki kedudukan yang berbeda dengan subjek hukum yang telah cakap melakukan perbuatan hukum.

Terkait dengan hal tersebut, seorang anak dibawah umur atau belum dewasa tidak memiliki kecakapan untuk melakukan sebuah perjanjian sebagaimana disebutkan dalam Pasal 1330 KUH Perdata, sehingga peralihan hak tersebut harus dilakukan oleh seseorang yang mewakili anak di bawah umur baik oleh orang tua maupun orang lain yang diangkat sebagai wali sesuai dengan peraturan hukum yang berlaku. Hal tersebut bertujuan agar kelak tidak terjadi tuntutan maupun gugatan dari pihak lain mengenai sah tidaknya kepemilikan tanah oleh pemegang hak yang baru.

Perbuatan hukum yang dilakukan oleh seorang anak diatur dalam Pasal 47 ayat (1) Undang-undang Nomor 1 Tahun 1974 tentang Perkawinan yang menyebutkan bahwa anak yang belum mencapai umur 18 tahun atau belum pernah melangsungkan perkawinan ada di bawah kekuasaan orang tuanya selama mereka tidak dicabut dari kekuasaannya. Pada ayat (2) Undang-undang tersebut mengatur bahwa orang tua mewakili anak tersebut mengenai perbuatan hukum didalam dan diluar pengadilan.

Pengaturan lebih lanjut diatur dalam Pasal 48 yang menyebutkan bahwa orang tua tidak diperbolehkan memindahkan hak atau menggadaikan barang-barang tetap yang dimiliki anaknya yang belum berumur 18 tahun atau belum pernah melangsungkan perkawinan, kecuali apabila kepentingan anak itu menghendakinya. Perwakilan oleh orang tua tersebut tidak serta merta berlaku dalam hal adanya pelepasan hak atas tanah yang 
dimiliki oleh seorang anak. Hal tersebut perlu diperhatikan karena dalam pelepasan hak atas tanah akan mengurangi hak seorang anak sehingga perlu ada perlindungan hukumnya.

Batas umur kedewasaan seseorang untuk cakap bertindak diatur dalam berbagai macam peraturan perundang-undangan yang penerapannya disesuaikan dengan perbuatan hukum apa yang hendak dilakukan. Usia 21 tahun merupakan ukuran kedewasaan menurut Pasal 330 KUH Perdata, sedangkan usia 18 tahun merupakan ukuran kedewasaan menurut Pasal 48 Undang-undang Nomor 1 Tahun 1974 tentang Perkawinan terkait adanya pemindahan hak oleh orang tua terhadap barang-barang tetap yang dimiliki anaknya, Pasal 1 angka 1 Undang-undang Nomor 23 Tahun 2002 tentang Perlindungan Anak terkait pengertian seorang anak, dan Pasal 39 ayat (1) a Undang-undang Nomor 2 Tahun 2014 tentang Perubahan atas Undang-undang Nomor 30 Tahun 2004 tentang Jabatan Notaris terkait syarat usia penghadap dalam pembuatan akta notaris. Pasal 37 ayat (1) Peraturan Pemerintah Nomor 24 Tahun 1997 tentang Pendaftaran Tanah menyebutkan bahwa pelepasan hak atas tanah merupakan kegiatan peralihan hak yang harus dilakukan dengan akta yang dibuat oleh Pejabat Pembuat Akta Tanah atau yang selanjutnya disebut PPAT. Hal ini dilakukan sebagai syarat pendaftaran peralihan hak atas tanah di Kantor Pertanahan. Proses pelepasan hak tersebut harus memperhatikan kedudukan hak atas tanah, apabila kepemilikannya bersama, maka harus mendapat persetujuan dari semua yang berhak atas tanah tersebut untuk dapat dilakukan jual beli termasuk juga adanya kepemilikan hak atas tanah oleh anak dibawah umur.

Oleh karena itu, pada prakteknya, untuk melindungi kepentingan anak di bawah umur diperlukan adanya penetapan pengadilan terkait perwakilan seseorang untuk bertindak dalam hal adanya pelepasan hak yang dimiliki oleh anak tersebut. Pengambilan keputusan yang dilakukan oleh hakim menjadi yurisprudensi dalam penerapan batas usia kedewasaan seseorang. Berbagai macam peraturan mengenai batas usia dewasa yang ada menyebabkan tidak adanya kepastian hukum sehingga penerapannya disesuaikan dengan perbuatan hukum apa yang hendak dilakukan.

Peranan hakim sebagai aparat kekuasaan kehakiman, pada prinsipnya tidak lain dari pada melaksananakan fungsi peradilan sesuai dengan ketentuan peraturan yang berlaku. Bagi hakim dalam mengadili suatu perkara terutama yang dipentingkan adalah fakta atau peristiwanya dan bukan hukumnya. Peraturan hukum hanyalah alat, sedangkan yang bersifat menentukan adalah peristiwanya.

\section{METODE PENELITIAN}

Jenis Penelitian ini termasuk Penelitian Lapangan (field research) yaitu Penelitian terhadap Peran Pejabat Pembuat Akta Tanah melalui Kantor PPAT, menggunakan metode pendekatan yang digunakan dalam penelitian ini adalah yuridis empiris. Yuridis empiris adalah pendekatan yang dilakukan untuk menganalisa sejauh mana aturan/hukum berlaku secara efektif. Dalam hal ini Yuridis digunakan untuk menganalisa berbagai peraturan perundang-undangan tentang peran PPAT dalam pembuatan akta jual-beli tanah yang mana subjek hukumnya adalah anak dibawah umur, sedangkan empiris dipergunakan untuk menganalisa sejauh mana masyarakat sadar hukum dalam hal pendaftaran hak atas tanah.

Penelitian ini dilaksanakan Di Kantor Notaris dan PPAT ERNA EFFENDI,S.H.,M.Kn., S.K Menteri Hukum dan Hak Asasi Manusia Republik Indonesia, Nomor AHU- 
01110.AH.02.01.TAHUN 2015, Tanggal 30 Nopember 2015, Jalan Raya Kuningan, Desa Kuningan, Kecamatan Kanigoro, Kabupaten Blitar, Telp/Fax (0342) 4551135.

Alasan memilih lokasi tersebut didasarkan pada pengertian bahwasanya PPAT merupakan pejabat umum yang diberi kewenangan untuk membuat akta-akta otentik mengenai perbuatan hukum tertentu dan mengenai hak atas tanah atau hak milik atas satuan rumah susun.

Penelitian ini bersifat deskriptif analitis. Deskriptif yang penulis maksud adalah bertujuan untuk menjelaskan secara komprehensif dan sistematik tentang Akta jual-beli tanah yang dibuat oleh P.P.A.T dengan subjek hukumnya adalah anak dibawah umur. Sedangkan analitis bertujuan untuk mengelompokan, menggambarkan dan membandingkan antara teori Peran Pejabat Pembuat Akta Tanah dan proses dalam pelaksanaan pendaftaran tanah untuk anak dibawah umur. Menurut Sugiyono, populasi adalah wilayah generalisasi yang terdiri atas subyek/obyek yang mempunyai kualitas dan karakteristik tertentu yang diterapkan peneliti untuk mempelajari dan kemudian ditarik kesimpulannya. ${ }^{11}$

Subyek atau pihak yang dijadikan sumber data dalam penelitian ini adalah Kantor Notaris dan P.P.A.T Erna Effendi, S.H.,M.Kn. Sedangkan Obyek dalam penelitian ini adalah Tinjauan Yuridis Akad Jual Beli Tanah Dengan Subjek Hukum Anak Dibawah Umur.

Dalam penelitian ini metode penentuan sampel yang dipergunakan adalah purposive sampling. Menurut Sugiyono, Purposive Sampling adalah teknik penentuan sampel dengan pertimbangan tertentu. ${ }^{2}$ Teknik ini dipilih karena alasan keterbatasan waktu, biaya dan tenaga. Data primer dalam penelitian ini berasal dari hasil penelitian dalam lokasi melalui pengamatan dan wawancara. Dalam penyusunan data primer, penyusun mendapatkan data dari kantor Notaris/PPAT. Sedangkan data sekundernya diperoleh dari studi kepustakaan baik itu berupa Buku-buku Literatur, Undang-undang, kamus, dan karya Ilmiah para Sarjana yang berkaitan dengan penelitian ini. Bahan-bahan sekunder yang digunakan adalah:

1. Kitab Undang-Undang Hukum Perdata;

2. Undang-Undang Nomor 5 Tahun 1960 tentang Peraturan Dasar Pokok-Pokok Agraria;

3. Undang-Undang Nomor 4 Tahun 1996 tentang Hak Tanggungan atas Tanah yang Berkaitan dengan Tanah, Pengertian Pejabat Pembuat Akta Tanah;

4. Peraturan Pemerintah Nomor 24 Tahun 1997 tentang Pendaftaran Tanah;

5. Peraturan Pemerintah Nomor 37 Tahun 1998 tentang Peraturan Jabatan Pembuat Akta Tanah;

6. Peraturan Menteri Negara/Kepala BPN Nomor 3 Tahun 1997 tentang Ketentuan Pelaksanaan Peraturan Pemerintah Nomor 24 Tahun 1997 tentang Pendaftaran Tanah.

7. Peraturan Kepala Badan Pertanahan Nasional Nomor 1 Tahun 2006 tentang Ketentuan Pelaksanaan Peraturan Pemerintah Nomor 37 Tahun 1998 tentang Peraturan Jabatan Pejabat Pembuat Akta Tanah;

8. Buku-buku yang berkaitan dengan PPAT;

9. Karya ilmiah/hasil penelitian para sarjana di bidang peran, fungsi dan kewenangan PPAT.

6. Teknik Pengumpulan Data

Tekhnik pengumpulan data merupakan cara yang dipakai untuk mengumpulkan informasi atau fakta-fakta di lapangan. Dalam pengumpulan data pada penelitian ini

\footnotetext{
1 Sugiyono, Metode Penelitian Administrasi, Bandung: Alfabeta, 2001,hlm.57

2 Sugiyono, Metode Penelitian Kuantitatif, Kualitatif dan R \& D, Bandung: Alfabeta: 2008, hlm.85,
} 
dilakukan beberapa metode yaitu sebelum dilakukan penelitian penyusun melakukan survei atau pra penelitian di Kantor Pejabat Pembuat Akta Tanah Kabupaten Blitar, penulis menggali informasi guna menemukan permasalahan dalam hal pendaftaran yang terjadi di Kabupaten Blitar. Setelah ditemukan permasalahan selanjutnya penyusun mengumpulkan berbagai literatur baik itu berupa Buku, peraturan Perundang-undangan maupun karya Ilmiah para Sarjana yang berhubungan dengan permasalahan yang akan diteliti oleh penulis. Setelah menemukan permasalahan dari hasil Pra Penelitian dan melakukan studi pustaka, selanjutnya penyusun berusaha melakukan pengamatan terhadap masyarakat Blitar.Observasi ini dimaksudkan agar memperoleh gambaran yang lebih jelas tentang kehidupan sosial di Kabupaten Blitar.

Dalam penelitian ini, penyusun melakukan wawancara kepada Pejabat Pembuat Akta Tanah yakni Kantor Notaris/PPAT ErnaEffendi, S.H.,M.Kn guna memperoleh informasi secara lisan terkait proses bagaimana tata cara pendaftaran peralihan hak atas tanah dengan subjek hukum anak dibawah umur. Di samping itu, penyusun juga berharap mendapat informasi lebih jauh tentang alasan yang timbul dalam pelaksanaan peralihan hak atas tanah.

Peneliti juga melakukan dokumentasi yaitu dengan cara menyalin data yang ada di Kantor Notaris/PPAT berupa data penetapan pengadilan negeri Blitar dalam perwalian. Setelah seluruh data berhasil dikumpulkan dan lengkap, tahap selanjutnya adalah melakukan analisa data. Analisa ini diharapkan agar data yang diperoleh dapat menjawab segala permasalahan yang mendasari penelitian ini. Secara umum, analisa dimaksudkan untuk memberikan penjelasan dan menginterpretasikan secara rasional sistemastis menuju cara berfikir yang deduktif-induktif yang sesuai dengan kaidah dalam penulisan karya ilmiah. Menurut Rusdi Pohan, Tujuan utama dari analisis data adalah untuk meringkaskan data dalam bentuk yang mudah dipahami dan mudah ditafsirkan, sehingga hubungan antara problem penelitian dapat dipelajari dan diuji. ${ }^{3}$ Data yang telah dikumpulkan akan dianalisis menggunakan analisa kualitatif, artinya menguji data yang diperoleh dengan perundang-undangan, teori-teori, maupun pendapat ahli sehingga dapat ditarik kesimpulan yang memadai sebagai karya penelitian.

Kecakapan seseorang dalam melakukan perbuatan hukum dikaitkan dengan dewasa secara fisik dalam hukum pertanahan bersandar kepada ketentuan Pasal 330 KUHPerdata yaitu "belum dewasa adalah mereka yang belum mencapai umur genap 21 tahun dan sebelumnya belum kawin", hal ini dapat dimaklumi karena tidak tegas mengenai ketentuan umur dewasa dalam hukum, terutama hukum adat yang dapat dijadikan dasar pengaturannya. ${ }^{4}$

Dalam melakukan jual beli tanah bersertipikat milik bersama anak di bawah umur tersebut harus dilengkapi dengan Surat Penetapan dari Pengadilan. Hal ini sesuai ketentuan Pasal 309 dan Pasal 393 KUHPerdata, pengalihan hak milik dari anak yang masih di bawah umur harus berdasarkan pada Penetapan dari Pengadilan.

Kewajiban adanya penetapan pengadilan dalam pendaftaran peralihan hak atas tanahdengan jual beli milik bersama anak di bawah umur pada Kantor Pertanahan adalah didasari pada KUH Perdata yaitu untuk melindungi kepentingan dari anak di bawah umur yang bersangkutan.

Menurut hukum, semua orang dalam keadaan cakap (bewenang) bertindak, sehingga mereka dapat melakukan perbuatan hukum, termasuk membuat atau menandatangani suatu perjanjian, kecuali mereka yang diatur dalam undang-undang. Mereka yang dikecualikan ini disebut orang yang tidak cakap (tidak berwenang) melakukan suatu tindakan hukum, yaitu pihak-pihak sebagai berikut:

a. Anak yang belum dewasa

b. Orang yang berada di bawah pengampuan

\footnotetext{
${ }^{3}$ Rusdi Pohan, Metode Penelitian Pendidikan, Bandung : PT. Citra Aditya Bakti, hlm. 77

${ }^{4}$ Ibid., hlm. 29
} 
c. Perempuan yang telah kawin dalam hal-hal yang ditentukan undang-undang dan pada umumnya semua orang yang oleh undang-undang dilarang untuk membuat persetujuan tertentu.Namun berdasarkan SEMA nomor 3/1963 juncto Pasal 31 Undang-undang nomor 1 tahun 1974, perempuan yang masih terikat dalam perkawinan sudah cakap melakukan perbuatan hukum sendiri

d. Orang yang dilarang oleh undang-undang untuk melakukan perbuatan tertentu

Jika salah satu atau kedua belah pihak dalam perjanjian ternyata tidak cakap berbuat, maka konsekuensi yuridisnya adalah sebagai berikut:

1. Jika perjanjian tersebut dibuat oleh anak di bawah umur (belum dewasa), maka perjanjian tersebut akan batal atas permintaan dari pihak anak yang belum dewasa tersebut, sematamata karena alasan belum dewasanya anak tersebut. Pasal 1446 ayat (1) KUH Perdata juncto Pasal 1331 ayat (1) KUH Perdata.

2. Jika perjanjian dibuat oleh orang yang berada di bawah pengampuan, maka perjanjian tersebut batal atas permintaan dari orang yang berada di bawah pengampuan tersebut, dengan alasan semata-mata karena keberadaannya di bawah pengampuan tersebut.

3. Perjanjian yang dibuat oleh orang-orang yang tidak cakap bertindak tersebut, yang kemudian dinyatakan batal, maka para pihak dalam perjanjian tersebut harus menempatkan perjanjian tersebut pada keadaan sebelum perjanjian dibuat, jadi perjanjian tersebut dianggap seolah-olah tidak ada. ${ }^{5}$

Salah satu syarat agar suatu perjanjian sah, perjanjian tersebut haruslah dibuat oleh orang yang cakap berbuat berdasarkan Pasal 1330 KUH Perdata, antara lain dibuat oleh orang yang sudah dewasa. Berdasarkan Pasal 330 KUH Perdata, orang yang belum dewasa menurut hukum adalah mereka yang belum mencapai umur genap 21 tahun dan belum pernah kawin sebelumnya. Oleh karena itu, apabila ditafsirkan secara terbalik, maka orang yang dianggap dewasa dan cakap berbuat menurut hukum adalah:

1. Sudah genap berumur 21 tahun

2. Sudah kawin, meskipun belum genap 21 tahun

3. Tidak berada di bawah pengampuan

\section{PENUTUP}

Pelaksanaan jual beli tanah yang dilakukan oleh anak dibawah umur yang berada dibawah perwalian atau kepada orang-orang yang terampu harus diterima si wali atau si pengampu, yang harus dikuasakan oleh pengadilan, karena jika tifak diwakili oleh wali maka akibat hukumnya adalah batal/tidak sah akad jual beli tersebut. Pelaksanaan jual-beli berdasarkan KUH Perdata harus dilakukan dengan jelas dan terang, yang dalam penerimaannya dilakukan dengan diwakili oleh wali dari anak tersebut, dalam hal ini hak perwalian pada keluarga sedarah atau semenda. Jika masalah timbul disebabkan tidak terpenuhinya tata cara jual beli, maka penyelesaiannya adalah mempertanyakan terlebih dahulu kepada PPAT tentang keabsahan akta tersebut, dalam hal ini maka akta yang sudah ada dapat diperbaharui tetapi terlebih dahulu dilakukan pembatalan akta baru setelah itu dibuatkan akta baru. Perlindungan terhadap harta kekayaan anak dibawah umur, maka pengurusannya dapat dilakukan melalui perwakilan orang tua atau perwalian anak dibawah umur, baik menurut undang-undang ataupun berdasakan penetapan pengadilan. Kekuasan perwakilan atau perwalian tidak boleh digunakan untuk memindah tangankan, mengalihkan atau membebankan harta kekayaan anak dibawah umur, kecuali kepentingan si anak menghendaki dan harus ada ijin dari pengadilan negeri. Kedudukan anak dibawah

\footnotetext{
${ }^{5}$ Munir Fuady. Konsep Hukum Perdata. Raja Grafindo Persada, Jakarta. 2014. hlm. 196-197
} 
usia dua puluh satu tahun atau sebelumnya belum pernah menikah, maka kedudukannya tidaklah sama dengan orang yang sudah dewasa. 


\section{DAFTAR PUSTAKA}

Buku:

Anim, Sudarwan, Perkembangan Peserta Didik. Bandung : Alfabeta. 2011.

Aprilia, Desy. "Implementasi Terhadap Jual Beli Yang Dilakukan Oleh Anak Dibawah Umur Dilihat Dari Perspektif KUH Perdata". Jurnal Ilmiah. Universitas Mataram. 2015.

Dibyo Yuwono, Petrus. "Penetapan Pengadilan Dalam Proses Pelaksanaan Jual Beli Hak Milik Atas Tanah Warisan". Tesis. Pascasarjana Universitas Diponegoro Semarang. 2009.

Fuady, Munir. Konsep Hukum Perdata, Jakarta: Raja Grafindo Persada. 2014.

G.H.S. Lumban Tobing, Peraturan Jabatan Notaris, Jakarta. Erlangga. 1992.

Harsono, Boedi. Hukum Agraria Indonesia, Sejarah Pembentukan Undang-Undang Pokok Agraria Isi dan Pelaksanaannya, Jakarta. Djambatan. 2003.

J Satrio, HukumPerjanjian (PerjanjianPadaUmumnya), Bandung : PT. Citra Aditya Bakti. 1992. Praitno, Meilani. "Analisis Yuridis Pembuatan Akta Pengikatan Jual Beli Tanah Yang Perbuatan Hukum Peralihan Haknya Didasarkan Pada Akta Pengikatan Jual Beli Tanah Yang Dibuat Sebelumnya Oleh Para pihak Yang sama". Tesis. Universitas Indonesia Depok. 2012.

Mandar Maju. 2011.

Pujilestari, Ningrum "Kecakapan Bertindak Dalam Melakukan PerbuatanHukum Setelah Berlakunya Undang-Undang No.30 Tahun 2004 Tentang jabatan Notaris". Tesis. Pascasarjana Universitas Diponegoro Semarang. 2008.

R. Subekti, Aneka Perjanjian, Jakarta : Intermasa. 1992.

S. Chandra, Sertifikat Kepemilikan Hak Atas Tanah, Persyaratan Permohonan Di Kantor Pertanahan, Jakarta: Gresindo. 2005.

Sjaifurrahman, Aspek Pertanggungjawaban Notaris dalam Pembuatan Akta, Bandung: CV.

Suheri. "Peralihan Hak Atas Tanah Dan Bangunan Karena Hibah Untuk Anak Dibawah Umur". Tesis. Pascasarjana Universitas Diponegoro Semarang. 2010.

Yamin Lubis, Mhd, dan Abd Rahim Lubis, Hukum Pendaftaran Tanah, Edisi Revisi, Bandung:CV.Mandar Maju. 2010.

\section{Peraturan Perundang-Undangan:}

Kitab Undang-Undang Hukum Perdata

Undang-Undang No. 5 Tahun 1960 tentang Peraturan Dasar Pokok-Pokok Agraria.

Undang-Undang No.1 Tahun 1974 tentang Perkawinan

Undang-Undang No. 4 tahun 1979 tentang Kesejahteraan Anak

Undang-Undang No. 3 tahun 1997 tentang Pengadilan Anak

Undang-Undang No. 23 tahun 2002 tentang Perlindungan Anak

Undang-Undang No. 12 tahun 2006 tentang Kewarganegaraan Republik Indonesia

Peraturan Pemerintah No. 37 tahun 1998 tentang Peraturan Jabatan Pejabat Pembuat Akta Tanah

Peraturan Kepala Badan Pertanahan Nasional No. 1 tahun 2006 tentang Ketentuan Pelaksanaan Peraturan Pemerintah Nomor 37 Tahun 1998 tentang Peraturan Jabatan Pejabat Pembuat Akta Tanah

Surat Edaran Menteri Dalam Negeri Direktorat Jenderal Agraria Direktorat Pendaftaran tanah (Kadaster), Tanggal : 13-7-1977, Nomor : Dpt.7/539/7-77, tentang Dewasa Hukum 
